\title{
Enrichment of Phosphoproteins and Phosphopeptide Derivatization Identify Universal Stress Proteins in Elicitor-Treated Arabidopsis
}

\author{
Marit Lenman, Carolin Sörensson, and Erik Andreasson \\ Department of Cell and Organism Biology, Lund University, Sölvegatan 35, SE-223 62 Lund, Sweden
}

Submitted 15 February 2008. Accepted 16 June 2008.

\begin{abstract}
Protein phosphorylation is a key biological process that regulates reactions involved in plant-microbe interactions. The phosphorylated form of a protein often represents only a small fraction of the total population and can be problematic to analyze in a mass spectrometer. We demonstrate how a titanium dioxide $\left(\mathrm{TiO}_{2}\right)$ resin can be employed for the enrichment of phosphoproteins, as well as a method to derivatize $\mathrm{TiO}_{2}$-purified phosphopeptides to facilitate determination of the exact site of phosphorylation. The use of these methods was exemplified by the identification of two plant proteins that were shown to be phosphorylated after the elicitation of Arabidopsis cells with Phytophthora infestans zoospores and xylanase. Both of the proteins that were identified, At5g54430.1 and At4g27320.1, were found to contain a universal stress protein domain with conserved residues for ATP binding.
\end{abstract}

Additional keywords: 4-sulfophenyl isothiocyanate, SPITC.

Protein phosphorylation is a key biological process regulating a large number of essential reactions in living organisms. The phosphorylation of serine, threonine, and tyrosine can affect protein structure, enzymatic activity, and subcellular localization, as well as interaction with other proteins. Analysis of phosphoproteins, including determination of phosphorylation sites with mass spectrometry (MS) analysis of peptides, is thus highly important for gaining an understanding of interactions between plants and microbes. This knowledge can be used for development of new methods to reduce effects of pathogen attacks, such as phosphomimic mutation of signaling intermediates.

Plants have developed many different mechanisms to counteract pathogen attack. Some of these defense mechanisms are preformed, providing physical and chemical barriers to hinder pathogen infection, whereas others are first induced when the presence of a pathogen has been perceived. Recognition of a pathogen or an elicitor leads to a variety of local and systemic changes that serve to kill the pathogen or prevent its spreading through the plant. The different layers of induced defense include basal defense and resistance $(R)$-gene-mediated defenses. Basal defense relies on the plant recognizing general elicitors, which are structural components of microbes. One fungal

Corresponding author: E. Andreasson; E-mail: Erik.Andreasson@cob.lu.se

* The $\boldsymbol{e}$-Xtra logo stands for "electronic extra" and indicates that a supplemental figure is published online. elicitor is xylanase, which can be a potent elicitor of defense responses in cultivars of the Solanaceae family. Ron and Avni (2004) were able to show that silencing of xylanase receptors prevents the binding of xylanase and, thus, inhibits the hypersensitive response in tomato. Interestingly, a kinase (AtMPK6) can be induced by different signaling pathways depending on whether a fungal or a bacterial elicitor is involved (Anthony et al. 2006).

Reversible protein phosphorylation is a key biological process for regulating pathogen-induced defense responses. Approximately $4 \%$ of all Arabidopsis proteins are predicted to be kinases, proteins that transfer a phosphate group to a substrate. In both basal and $R$-gene-mediated defenses, phosphorylation cascades can be activated within minutes. The specific and irreversible inactivation of mitogen-activated protein kinase (MAPK) pathways by bacterial effectors injected by the type III secretion system, and the fact that potato plants have been engineered to be resistant to Phytophthora infestans by superactivation of a MAPK pathway, both illustrate how important phosphorylation can be in plant-pathogen interactions (Shan et al. 2007; Yamamizo et al. 2006).

Different Phytophthora spp. are among the most devastating pathogens of dicot plants. $P$. infestans caused the Irish potato famine some 160 years ago and, since then, has been a major problem in potato production. $P$. infestans causes a premature wilting and tuber blight. This plant pathological problem is presently on the increase due to sexual reproduction of the oomycete and due to fungicides having become less efficient. The general public has also shown considerable concern regarding the use of fungicides. Arabidopsis exhibits a nonhost resistance to $P$. infestans and, therefore, is an attractive source of resistance to investigate.

Signaling proteins are often of low abundance and the phosphorylated form of the protein usually constitutes only a small fraction of the total population. Therefore, several different methods for phosphoprotein enrichment have been developed. Immunoprecipitation with antibodies specific to phosphorylated amino acid residues have been used but the technique suffers from the limited availability of effective anti-pSer/pThr antibodies. Selective enrichment of phosphoproteins by the use of immobilized metal-affinity chromatography (IMAC) and of metal hydroxide has also been described (Collins et al. 2005 $\left[\mathrm{Ga}^{3+}\right]$; Dubrovska and Souchelnytskyi $2005\left[\mathrm{Fe}^{3+}\right]$; Machida et al. $2007\left[\mathrm{Ga}^{3+}, \mathrm{Fe}^{3+}, \mathrm{Zn}^{2+}\right.$, and $\left.\mathrm{Al}^{3+}\right]$; Wolschin et al. 2005 $\left.\left[\mathrm{Al}(\mathrm{OH})_{3}\right]\right)$.

Identification of phosphopeptides can be limited by their relatively low abundance and their ion suppression during 
analysis in a mass spectrometer. Several techniques for the enrichment of phosphopeptides, including IMAC (Witze et al. 2007) and strong cation exchange chromatography (Beausoleil et al. 2004), have been employed. Recently, titanium dioxide $\left(\mathrm{TiO}_{2}\right)$ purification of phosphopeptides has been successfully carried out (Bodenmiller et al. 2007; Caspersen et al. 2007; Larsen et al 2005; Macek et al. 2007; Thingholm et al. 2006), but purification of intact phosphoproteins on $\mathrm{TiO}_{2}$ has not yet been described.

The tendency of phosphopeptides to lose phosphoric acid can make it difficult to determine the exact site of phosphorylation. Methods for improving the assignment and sequence coverage of phosphopeptides include comparison of untreated with phosphatase-treated samples, as well as specific chemical modification of phosphopeptides that are important especially in analyses with time of flight (TOF) instruments. Modification of phosphorylated residues can be achieved by $\beta$-elimination using $\mathrm{BaOH}$ but is difficult to carry out successfully if the residue is followed by a proline (Adamczyk et al. 2001). This is a major drawback because S/TP sequences are common targets for large groups of kinases, such as cyclin-dependent kinases and MAPKs.

Fragmented peptide matrix-assisted laser desorption ionization (MALDI) MS/MS spectra typically contain $\mathrm{y}$ and $\mathrm{b}$ and sometimes a, c, and $\mathrm{z}$ ions. General chemical derivatization methods that produce $y$-ion-dominated spectra have been used primarily in de novo sequencing. These methods include $\mathrm{N}$ terminal derivatization by use of 3-sulphopropionic acid NHSester (Keough et al. 1999) or 4-sulfophenyl isothiocyanate (SPITC) (Chen et al. 2003; Gevaert et al. 2001), both of these resulting in a strong negative charge at the $\mathrm{N}$-terminus and, thus, in an enhancement of the y-ion series. The effectiveness of these derivatization methods could be expected to be independent on the site of phosphorylation but the methods have not yet been applied to phosphopeptides from biological samples.

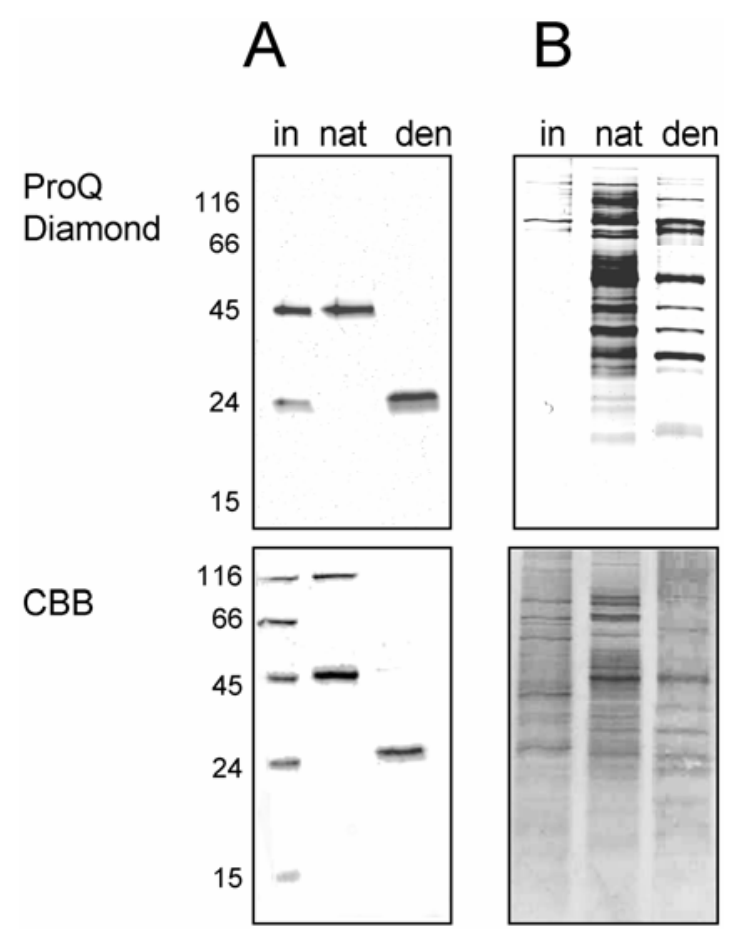

Fig. 1. Phosphoprotein enrichment by titanium dioxide $\left(\mathrm{TiO}_{2}\right)$ resin under native and denaturing conditions. Upper panel, Pro-Q Diamond staining; lower panel, Coomassie brilliant blue (CBB) staining. A, PeppermintStick phosphoprotein mix; B, Arabidopsis cell culture extract; in, input; nat, eluate with native buffer; den, eluate with denaturating buffer.
The importance of phosphorylation emphasizes the need for characterizing plant-microbe-mediated protein phosphorylation and identifying the phosphorylation sites in these proteins to obtain a better understanding of the biological role of the modification. This could serve as a basis for developing new methods of reducing the effects of pathogen attack. We describe two new signaling intermediates in the interaction between $P$. infestans and plants, as well as the development of methods for enrichment of phosphoproteins and the derivatization of phosphopeptides.

\section{RESULTS}

\section{Phosphoprotein enrichment.}

In efforts to discover phosphorylated signaling intermediates that take part in the response of plants to Phytophthora spp., we decided to develop a method for enrichment of phosphoproteins with $\mathrm{TiO}_{2}$ Sachtopore NP beads that had been employed recently for phosphopeptide enrichment (Larsen et al. 2005; Witze et al. 2007). We first used a standard mix of six proteins, of which two are phosphorylated (PeppermintStick mix; Molecular Probes, Eugene, OR, U.S.A.). With this material, a determination of whether native or denaturing conditions should be used and quantitative analyses of the recovery of phosphoproteins could be done. The protein $(2 \mu \mathrm{g}$ of each) was mixed with $200 \mu \mathrm{l}$ of the respective buffer and $20 \mathrm{mg}$ of $\mathrm{TiO}_{2}$ beads. This was incubated with shaking for $2 \mathrm{~h}$ and the beads were washed four times with $1 \mathrm{ml}$ binding buffer and were subsequently eluted three times with $200 \mathrm{mM} \mathrm{Na} \mathrm{HPO}_{4}$ and $100 \mathrm{mM}$ sodium pyrophosphate (NaPP with or without urea). After sodium dodecyl sulfate polyacrylamide gel electrophoresis (SDS-PAGE) separation, the gels were first analyzed for phosphoproteins by staining them with Pro-Q Diamond (Molecular Probes) (Fig. 1A, upper panel), and then with Coomassie brilliant blue (CBB) for detection of proteins (Fig. 1A, lower panel). A specific detection of phosphoproteins was indicated by the lack of staining of the nonphosphorylated proteins whereas the two phosphoproteins at 45 and $23 \mathrm{kDa}$ could be readily detected (Fig. 1A). Surprisingly, we found that, in order to enrich the two phosphoproteins, we needed to use both native and denaturing conditions because each method enriched only one of the proteins (Fig. 1A). Quantification of the ProQ-diamond signals from two independent experiments revealed that, under native conditions, $49 \%$ of the $45-\mathrm{kDa}$ protein was recovered and, under denaturating conditions, $34 \%$ of the $23-\mathrm{kDa}$ protein was recovered. Both the phosphoenrichment buffers efficiently removed unphosphorylated proteins from the mix, with the tendency for the denaturating conditions to contain even less nonphosphorylated proteins (Fig. 1A, lower panel). Analyses of the nonbound fractions showed that the 45-kDa protein did not bind in the denaturating buffer (data not shown). Boiling the beads with SDS buffer showed that, in native conditions, the $23-\mathrm{kDa}$ phosphoprotein was bound to the beads and did not elute using the sodium phosphate- and sodium pyrophosphate-containing buffer (data not shown).

After the demonstration of the use of $\mathrm{TiO}_{2}$ beads for enrichment of phosphoproteins from the mix with low complexity, we investigated whether the method was efficient on biologically relevant samples. Proteins from 4-day-old green cell cultures of Arabidopsis thaliana were extracted under native conditions and samples were diluted with 5 volumes of either extraction buffer or $8 \mathrm{M}$ urea before addition of beads. After $2 \mathrm{~h}$ of binding, the beads were washed and proteins were eluted with vigorous shaking in elution buffer with or without $6 \mathrm{M}$ urea. Again, the gels were first analyzed for phosphoproteins by staining them with Pro-Q Diamond (Fig. 1B, upper panel), and then with $\mathrm{CBB}$ for detection of proteins (Fig. 1B, lower panel). Phos- 


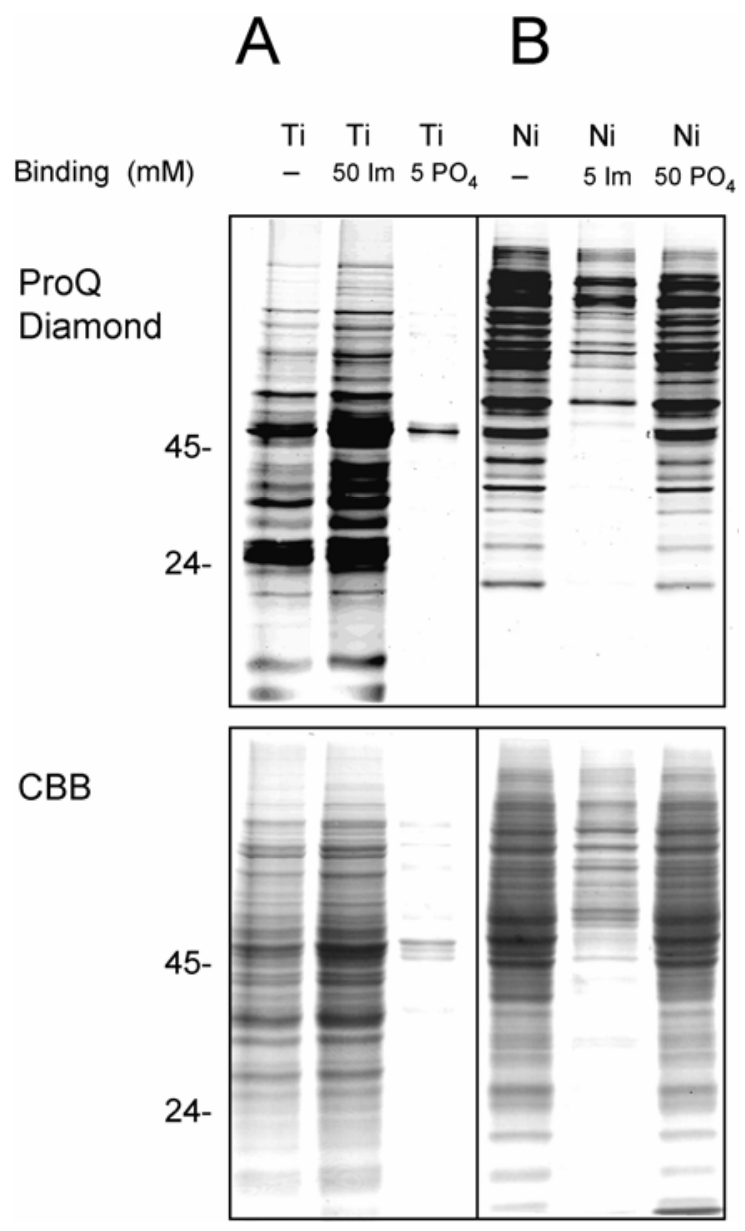

Fig. 2. Enrichment of phosphoproteins in native conditions with different resins. A, Titanium dioxide $\left(\mathrm{TiO}_{2}\right)$ purification. B, Ni-NTA purification. Upper panel, Pro-Q Diamond staining; lower panel, Coomassie brilliant blue (CBB) staining. $\mathrm{Ti}$, eluate from $\mathrm{TiO}_{2}$ purification; $\mathrm{Ni}$, eluate from $\mathrm{Ni}$ NTA purification; $50 / 5 \mathrm{Im}$, binding in buffer containing 50 or $5 \mathrm{mM}$ imidazole; $5 / 50 \mathrm{PO}_{4}$, binding in buffer containing 5 or $50 \mathrm{mM} \mathrm{Na}_{2} \mathrm{HPO}_{4}$. phoprotein-enrichment was evident in both buffer systems compared with the total protein extract (Fig. 1B, lane "in"). The patterns of phosphoproteins after enrichment were only partially overlapping again, indicating that both native and denaturing conditions could be used in order to get a more comprehensive phosphoprotein analysis. Varying the $\mathrm{pH}$ of the extraction buffer for the $\mathrm{TiO}_{2}$ enrichments from $\mathrm{pH} 6.5$ to 8.0 did not affect the overall pattern (data not shown).

For comparative studies of the $\mathrm{TiO}_{2}$ resin, we tested an IMAC resin (Ni-NTA beads) using $100 \mathrm{mM}$ imidazole and 100 $\mathrm{mM} \mathrm{Na} \mathrm{PO}_{4}$ for elution. Phosphoprotein enrichment under native conditions was evident by both resins (Fig. 2). The phosphoprotein patterns in the eluates from respective beads revealed clearly different profiles that suggest that the two resins are complementary to each other.

When proteins were enriched on $\mathrm{TiO}_{2}$ beads, adding $5 \mathrm{mM}$ sodium phosphate in the binding buffer clearly reduced the binding of proteins to the beads (Fig. $2 \mathrm{~A}$, lane labeled " $5 \mathrm{PO}_{4}$ "). Including imidazole in the binding buffer was not found to decrease the recovery of proteins or phosphoproteins (Fig. 2A). The presence of sodium pyrophosphate $(10 \mathrm{mM})$ and glycerophosphate $(10 \mathrm{mM})$ in the extraction and binding buffer resulted in the complete absence of proteins in the eluate (data not shown).

Omitting imidazole in the elution buffer led to there being no detectable level of proteins in the Ni-NTA eluate (data not shown). Binding to the Ni-NTA beads in the presence of $5 \mathrm{mM}$ imidazole clearly reduced the recovery of proteins from the resin, whereas inclusion of $50 \mathrm{mM}$ sodium phosphate in the binding buffer had little effect on the protein or phosphoprotein patterns (Fig. 2B). In contrast to titanium-based enrichment, the presence of sodium pyrophosphate and glycerophosphate in the extraction and binding buffer did not reduce the amount of phosphoproteins obtained from the Ni-NTA beads (data not shown). Thus, although both resins enriched phosphoproteins, they differed in their interaction with the proteins. The binding to the $\mathrm{TiO}_{2}$ beads was found to be dependent upon the presence of phosphate and not of imidazole, whereas the opposite was the case for the Ni-NTA resin.

Table 1. Identified phosphoproteins after single $\mathrm{TiO}_{2}$ enrichment of proteins from Arabidopsis cell culture under native (N) and denaturing (D) conditions ${ }^{\mathrm{a}}$

\begin{tabular}{|c|c|c|c|c|c|}
\hline $\begin{array}{l}\text { Accession } \\
\text { number }\end{array}$ & Buffer & $\begin{array}{c}\text { Peptide } \\
\text { count }\end{array}$ & $\begin{array}{l}\text { Total ion } \\
\text { score }\end{array}$ & $\begin{array}{l}\text { Best ion } \\
\text { score }\end{array}$ & Protein name \\
\hline AT1G76180.1 & $\mathrm{D}$ & 8 & 648 & 181 & Dehydrin (ERD14) \\
\hline AT1G48920.1 & $\mathrm{D}+\mathrm{N}$ & $8+1$ & $483+141$ & $118+141$ & Nucleolin, putative \\
\hline AT5G22650.1 & $\mathrm{D}+\mathrm{N}$ & $6+1$ & $438+57$ & $108+57$ & Expressed protein \\
\hline AT3G15730.1 & $\mathrm{N}$ & 7 & 394 & 125 & Phospholipase $\mathrm{D} \alpha 1$ (PLD $\alpha 1)$ \\
\hline AT1G56070.1 & $\mathrm{D}+\mathrm{N}$ & $5+12$ & $393+1,144$ & $166+190$ & Elongation factor 2 \\
\hline AT3G52990.1 & $\mathrm{D}+\mathrm{N}$ & $1+4$ & $180+420$ & $180+222$ & Pyruvate kinase, putative \\
\hline AT4G31580.1 & $\mathrm{D}+\mathrm{N}$ & $3+2$ & $147+65$ & $73+42$ & Splicing factor RSZp22 (RSZP22) \\
\hline AT3G49430.1 & $\mathrm{D}$ & 3 & 120 & 55 & Pre-mRNA splicing factor SF2 \\
\hline AT5G15450.1 & $\mathrm{N}$ & 1 & 93 & 93 & Heat shock protein 100 (HSP100), putative \\
\hline AT5G47210.1 & $\mathrm{D}+\mathrm{N}$ & $1+1$ & $43+83$ & $43+83$ & Nuclear RNA-binding protein, putative \\
\hline AT3G13920.1/ & & & & & \\
\hline AT1G54270.1 & $\mathrm{N}$ & 2 & 81 & 64 & Eukaryotic translation initiation factor $4 \mathrm{~A}-1 / 2$ \\
\hline AT3G55460.1 & $\mathrm{D}$ & 1 & 80 & 82 & SC35-like splicing factor, $30 \mathrm{kDa}$ (SCL30) \\
\hline AT5G43830.1 & $\mathrm{N}$ & 1 & 73 & 73 & $\begin{array}{l}\text { Expressed protein, similar to auxin downregulated protein ARG10 (Vigna } \\
\text { radiata) }\end{array}$ \\
\hline AT5G54430.1 & $\mathrm{N}$ & 1 & 60 & 60 & Universal stress protein (USP) family protein \\
\hline AT3G48050.1 & $\mathrm{N}$ & 1 & 54 & 54 & Bromo-adjacent homology (BAH) dom /AT3G48060.1-containing protein \\
\hline AT2G01210.1 & $\mathrm{D}$ & 1 & 45 & 45 & Putative LRR transmembrane protein kinase \\
\hline AT1G20630.1 & $\mathrm{N}$ & 1 & 44 & 44 & Catalase 1, CAT1 \\
\hline AT5G61780.1 & $\mathrm{N}$ & 1 & 41 & 41 & $\begin{array}{l}\text { Tudor domain-containing protein/nuclease family protein, contains Pfam domain } \\
\text { PF00567 }\end{array}$ \\
\hline AT1G24180.1 & $\mathrm{D}$ & 1 & 40 & 40 & Pyruvate dehydrogenase E1 component $\alpha$ subunit, putative \\
\hline AT5G52040.2 & $\mathrm{N}$ & 1 & 33 & 33 & Arginine/serine-rich splicing factor RSP41 \\
\hline
\end{tabular}

${ }^{a}$ Dataset is generated from tandem mass spectrometry data of one sample from each buffer. The ion scores were generated by Mascot searches of the Arabidopsis thaliana TAIR database with carbamidometyl as fixed modification and phosphorylated S, T, Y, and oxidized M as variable modifications. Only peptides with rank 1 are included. 
To show the general applicability of $\mathrm{TiO}_{2}$ beads for phosphoprotein-enrichment, we digested the $\mathrm{TiO}_{2}$-enriched plant proteins shown in Figure 1 with trypsin and analyzed them by MS. Twenty phosphoproteins were identified from two single high-pressure liquid chromatography (HPLC) MS/MS samples enriched under native and denaturating conditions (Table 1). The spectra are collected in Supplementary Figure 1. Only a third of the phosphoproteins were overlapping between the two samples, again showing that a screen using both buffers could be useful. The assignments as phosphoproteins were done with comparison to the PhosPhAt 2.1 database, where only experimentally verified phosphopeptides were taken into account. In addition to this study on complex samples, several phosphoproteins have been identified from gel pieces such as nucleoside diphosphate kinase 1 NDK1 (At4g09320.1) and ribosomal protein S6 RPS6 (AT4G31700.1).

\section{Stress-induced phosphorylation.}

To investigate the interaction between plants and $P$. infestans as well as to evaluate the use of the established phosphoprotein enrichment methods for the comparison of different samples, the Arabidopsis cell-suspension cultures were treated with xylanase or $P$. infestans zoospores. The proteins obtained were purified under native conditions on $\mathrm{TiO}_{2}$ or Ni-NTA beads, separated on SDS-PAGE, and stained with Pro-Q Diamond and CBB (Fig. 3). Two bands with apparent molecular weight of approximately $30 \mathrm{kDa}$ showed an increase in Pro-Q Diamond staining after 15 min of elicitation with xylanase and Phytophthora spp. Interestingly, the bands were hardly detected in the control sample whereas distinct bands were visible in the stressed samples after $\mathrm{TiO}_{2}$ enrichment (Fig. 3A). In contrast, we could not detect any differences in protein staining of the two bands in control and treated samples from the $\mathrm{Ni}$ beads (Fig. 3B). This indicates that the two resins bind these
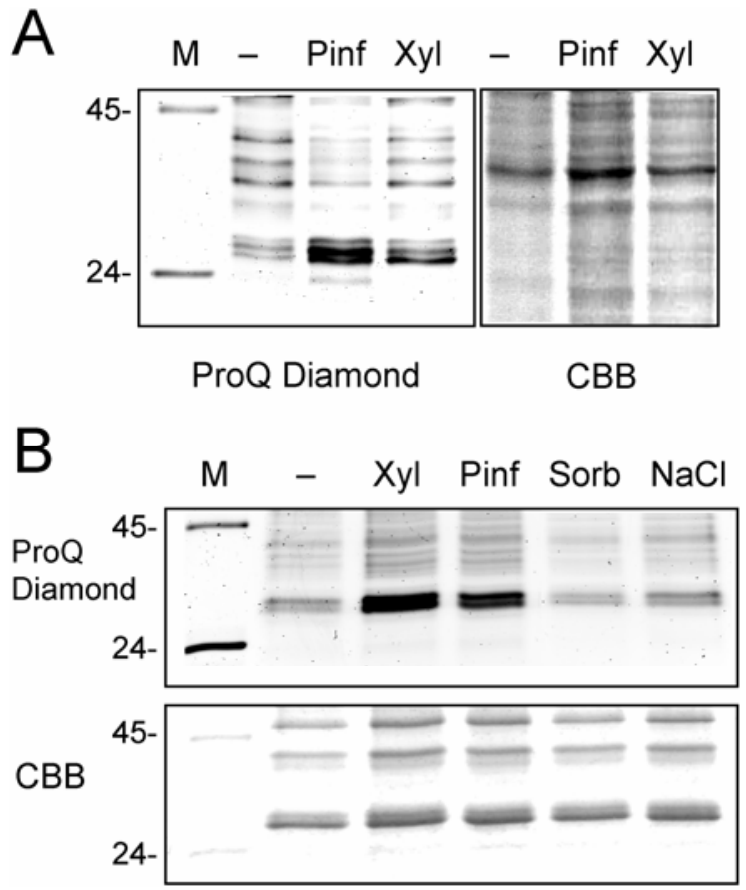

Fig. 3. Phytophthora infestans and xylanase-induced protein phosphorylation in Arabidopsis cells. A, Titanium dioxide $\left(\mathrm{TiO}_{2}\right)$ purification. B, NiNTA purification. Elicitation was done either with 3,000 zoospores per milliliter, xylanase at $100 \mu \mathrm{g} / \mathrm{ml}, 0.1 \mathrm{M} \mathrm{NaCl}$, or $0.2 \mathrm{M}$ sorbitol for 15 min. These experiments have been repeated three times with similar results. M, PeppermintStick phosphoprotein molecular weight marker; -, control with no treatment; Pinf, Phytophthora infestans zoospores; Xyl, xylanase; Sorb, sorbitol; and CBB, Coomassie brilliant blue. proteins differently and that $\mathrm{TiO}_{2}$ beads discriminated between the phosphorylated and unphosphorylated form of these proteins better than the Ni-beads. The results from the Ni-resin also show that no protein accumulation occurred during the $15 \mathrm{~min}$ of elicitation and that the difference in Pro-Q Diamond staining of the control and treated samples is only due to increased phosphorylation.

The biotic stress induction that we detected prompted us to test how specific this increase in phosphorylation was. Abiotic stress such as salt stress with $0.1 \mathrm{M} \mathrm{NaCl}$ or osmotic shock by $0.2 \mathrm{M}$ sorbitol did not alter the phosphorylation level of the two proteins (Fig. 3B). This might indicate a specific involvement in biotic stress of these proteins.

The differentially phosphorylated proteins were cut out from the gel, digested with trypsin, and analyzed by MALDI TOF MS (Fig. 4). The band of lower molecular weight was identified as being an Arabidopsis protein of unknown function (At5g54430.1) with similarity to bacterial universal stress proteins (USPs). The protein coverage was 54\%. All the major peaks in the MS spectra originated from this protein (Fig. 4A and C). Peaks not matching the protein identified were used to search the Arabidopsis database but no additional protein could be identified. The higher molecular band was identified as At4g27320.1 (Fig. 4B and D). These two proteins belong to the same protein family and have a sequence identity with each other of more than $80 \%$ (Fig. 4B). The MALDI run of the At4g27320.1 and At5g54430.1 protein digests was then analyzed for the presence of phosphorylated peptides but none were found. This could be due either to low abundance of the phosphorylated peptides or to ion suppression of them during the MALDI analysis.

\section{Phosphopeptide enrichment and analysis.}

With the aim of purifying phosphopeptides from At5g54430.1 and At4g27320.1, conditions for $\mathrm{TiO}_{2}$ purification were tested out using a mixture of trypsin-digested $\alpha$ - and $\beta$-casein. The protocol was based on Zhang and associates (2007), although $\mathrm{TiO}_{2}$ beads from Sachtopore instead of from GL Science were employed. Briefly, the peptide mixture was diluted five times with a binding buffer $(80 \%$ acetonitrile $[\mathrm{ACN}]$ and $5 \%$ trifluoro acetic acid [TFA]) and was then purified on a homemade column containing $\mathrm{TiO}_{2}$ beads. Peptides were eluted with ammonia and were then purified on a homemade POROS OLIGO R3 reverse phase (R3) column. Use of $1.5 \% \mathrm{NH}_{4} \mathrm{OH}$ instead of $0.5 \%$ for elution of the $\mathrm{TiO}_{2}$ column improved the recovery of phosphopeptides. Using $0.6 \%$ TFA for washing instead of a $0.1 \%$ solution (which is more often used) led to a higher recovery of phosphopeptides from the R3 column than the latter concentration yields (data not shown) (Larsen et al. 2005; Thingholm et al. 2006). Prepacked $\mathrm{TiO}_{2}$ Nutip columns from Glygen were also tried but were found, in our hands at least, to be of no great benefit.

Applying the improved protocol, trypsin digests of At4g27320.1 and At5g54430.1 were purified on $\mathrm{TiO}_{2}$ columns and desalted on R3 columns before the MALDI MS analyses. One peptide from each band was found at $\mathrm{m} / \mathrm{z} 1,020$ and 1,010 , respectively (Fig. 5A) (data not shown). These correspond in mass to phosphorylated forms of the IHHPPSPR $(\mathrm{m} / \mathrm{z}$ 940.6, At4g27320.1) and the IHHPSSPR (m/z 930.6, At5g54430.1) peptides present in the original MALDI MS spectra (Fig. 4A) (data not shown). Neither of the putative phosphopeptides was present in the original spectra. The phosphopeptides were in the N-terminal part of At4g27320.1 and At5g54430.1.

To verify the identity of the peptides and to determine the phosphorylation sites, the peptides purified by $\mathrm{TiO}_{2}$ were analyzed by MALDI MS/MS. MS/MS spectra of the 1,020- and 
1,010-m/z peptides are shown in Figure 6. Both peptides clearly show a neutral loss of $\mathrm{H}_{3} \mathrm{PO}_{4}\left(-98\right.$, denoted as $\left.\mathrm{M}^{\Delta}\right)$ and a neutral loss of $\mathrm{HPO}_{3}\left(-80\right.$, denoted as $\left.\mathbf{M}^{\#}\right)$, indicating that they are indeed phosphorylated. Both spectra contain b- as well as $y$-ions. The $y$-ion series of the $1,020-\mathrm{m} / \mathrm{z}$ peptide includes a phosphorylated y5 ion (m/z 633) and y3 ion $(\mathrm{m} / \mathrm{z} 439)$, a y5 ion that has undergone neutral loss $\left(\mathrm{y}^{\Delta}, \mathrm{m} / \mathrm{z} 535\right)$, and an unphosphorylated $\mathrm{y} 2$ ion $(\mathrm{m} / \mathrm{z} 272)$. This shows the phosphogroup to be located on the only serine residue that is present in the peptide (Fig. 6A). In the 1,010-m/z spectra, the presence of the $\mathrm{m} / \mathrm{z} 623(\mathrm{y} 5), 525\left(\mathrm{y} 5^{\Delta}\right)$, and $272(\mathrm{y} 2)$ ions localizes the phosphogroup to the PSS fragment, although it is not possible to determine its exact position (Fig. 6B).

\section{SPITC derivatization of phosphopeptides.}

The tendency of phosphopeptides to lose phosphoric acid can make it difficult to resolve the site at which phosphorylation takes place. A chemical derivatization method that produces y-ion-dominated spectra is $\mathrm{N}$-terminal derivatization by SPITC. The resulting peptide has a strong negative charge at the N-terminus, thereby enhancing the y-ion series. To our knowledge, SPITC derivatization has not previously been shown for phosphopeptides obtained from biological samples. We tested the possibility of applying this general and cheap modification method on $\mathrm{TiO}_{2}$-purified phosphopeptides because this derivatization method could be expected to be independent of the site of phosphorylation.

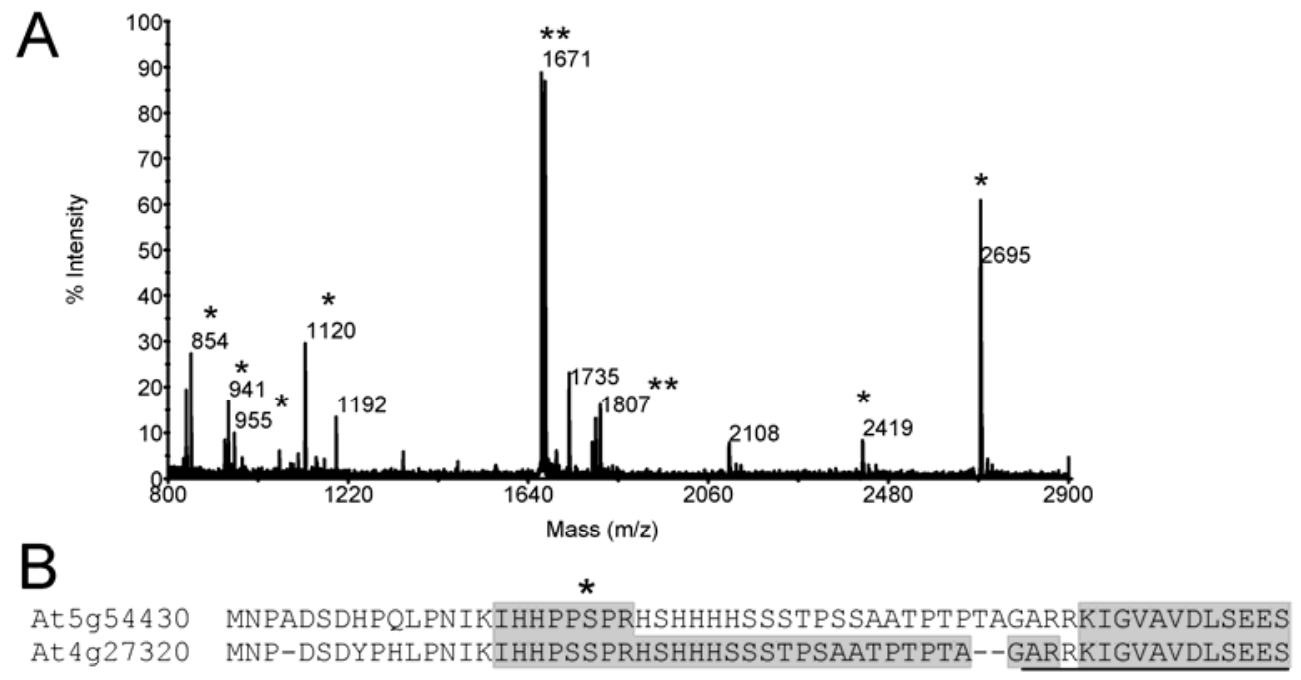

At5g54430 SFAVRWAVDHYIRPGDAVVLLHVSPTSVLFGADWGPLPLKTQ-----IEDPNAQPQPSQE At $4 \mathrm{~g} 27320$ AFAVRWAVDHYIRPGDAVVILHVSPT SVLFGADWGPLPLQTPPPPSAATDPGAQPKPSOE

At5g54430 DFDAFTSTKVADLAKPLKELGFPYKIHIVKDHDMRERLCLE IERLGLSAVIMGSRGFGAE At 4g27320 DFDAFTSSKVADLAKPLKEAGFPHKIHIVKDHDMRERLCLETERLNLSAVIMGSRGFGAE

At5g54430 KKRGSDGKLGSVSDYCVHHCVCPVVVVRYPDDRDGPVP----------IVTVKS------

At $4 \mathrm{~g} 27320$-KRGSDGKLGSVSDYCVHHCVCPVVVVRYPDDRDGPAPPGNVGATREAIVTVKSRRDDDD

At5g54430 -GGDDDGDVVAASASAHHEHIKDE 242

At $4 \mathrm{~g} 27320$ DDDEDHEAKIAAAASDHHEHIKDE 260

C

\begin{tabular}{|l|l|l|}
\hline Peptide & $\mathbf{~} / \mathbf{z}$ & Modification \\
\hline ELGFPYK & 853.45 & \\
\hline LCLEIER & 875.47 & \\
\hline IHHPPSPR & 940.51 & \\
\hline IHHPPSPR & 956.51 & Oxidation (HW) \\
\hline VADLAKPLK & 954.60 & \\
\hline LGLSAVIMGSR & 1103.62 & \\
\hline LGLSAVIMGSR & 1119.62 & Oxidation (M) \\
\hline IHIVKDHDMR & 1263.66 & \\
\hline YPDDRDGPVPIVTVK & 1670.87 & \\
\hline IGVAVDLSEESSFAVR & 1678.86 & \\
\hline VADLAKPLKELGFPYK & 1789.03 & \\
\hline KIGVAVDLSEESSFAVR & 1806.96 & \\
\hline TQIEDPNAQPQPSQEDFDAFTSTK & 2694.22 & \\
\hline HSHHHHSSSTPSSAATPTPTAGAR & 2419.12 & \\
\hline SGGDDDGDVVAASASAHHEHIKDE & 2419.04 & \\
\hline
\end{tabular}

D

\begin{tabular}{|l|l|l|}
\hline Peptide & $\mathbf{m} / \mathbf{z}$ & Modification \\
\hline IHHPSSPR & 930.49 & \\
\hline IHHPSSPR & 946.49 & Oxidation (HW) \\
\hline LNLSAVIMGSR & 1160.65 & \\
\hline DGPAPPGNVGATR & 1208.63 & \\
\hline IHIVKDHDMR & 1263.66 & \\
\hline IHIVKDHDMR & 1279.66 & Oxidation (M) \\
\hline IGVAVDLSEESAFAVR & 1662.87 & \\
\hline KIGVAVDLSEESAFAVR & 1790.96 & \\
\hline YPDDRDGPAPPGNVGATR & 1870.90 & \\
\hline HSHHHSSSTPSAATPTPTAGAR & 2195.03 & \\
\hline HSHHHSSSTPSAATPTPTAGAR & 2227.03 & 2 Oxidation (HW) \\
\hline
\end{tabular}

Fig. 4. Matrix-assisted laser desorption ionization dual mass spectrometry (MALDI MS) analysis of proteins that are phosphorylated after stress. A, MALDI MS spectra of trypsin-cleaved band from the lower band. Asterisks denote peaks that belong to At5g54430.1. B, Protein alignment of At5g54430.1 and At4g27320.1. Peptides identified by MS are shaded. The universal stress protein domain is underlined. The asterisk denotes identified phosphorylated residues that were phosphorylated after Phytophthora elicitation. C, Identified At5g54430.1 peptides. It was not possible to assign two peptides (shown in italics) from At5g54430.1 due to a minor difference in size. D, Identified peptides from At4g27320.1. 
The derivatization method was developed using the At5g54430.1 phosphopeptide of $\mathrm{m} / \mathrm{z} 1,020$ purified on $\mathrm{TiO}_{2}$. $\mathrm{TiO}_{2}$ eluate $(20 \mu \mathrm{l})$ in ammonia $(\mathrm{pH} 11)$ was mixed with $10 \mu \mathrm{l}$ of SPITC at $20 \mathrm{mg} / \mathrm{ml}$ in $100 \mathrm{mM} \mathrm{NaHCO}$ and $10 \mu \mathrm{l}$ of $3.3 \%$ formic acid (in order to adjust the $\mathrm{pH}$ to 8.5 ). The mixture was incubated at $55^{\circ} \mathrm{C}$ for $15 \mathrm{~min}$. An additional $5 \mu \mathrm{l}$ of SPITC was added and the sample was incubated again for $15 \mathrm{~min}$ at $55^{\circ} \mathrm{C}$. After acidification with $2.2 \mu \mathrm{l}$ of concentrated formic acid, the derivatized phosphopeptide was purified on R3 resin and analyzed by MALDI MS (Fig. 5B). An underivatized sample was analyzed as a control (Fig. 5A). Comparison of the two MS spectra showed the method developed here to be highly effective in derivatizing the $\mathrm{m} / \mathrm{z} 1,020$ phosphopeptide into $\mathrm{m} / \mathrm{z} 1,235$ (+215 Da).

MS/MS analysis of the underivatized $\mathrm{m} / \mathrm{z}$ 1,010 phosphopeptide from At4g27320.1 showed there to be two possible sites of phosphorylation, each of them labeled by a question mark in Figure 7A. Accordingly, a $\mathrm{TiO}_{2}$-enriched sample was SPITC derivatized and MS/MS spectra were collected from the derivatized phosphopeptide of $\mathrm{m} / \mathrm{z}$ 1,225 (Fig. 7B). The most abundant fragment peak corresponds to the mass of the underivatized phosphorylated peptide, resulting from loss of

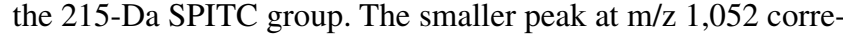
sponds to a 173-Da loss of sulphanic acid $\left(\mathrm{HO}_{3} \mathrm{~S}-\mathrm{C}_{6} \mathrm{H}_{4}-\mathrm{NH}_{2}\right)$. Peaks matching the loss of phosphoric acid (-98) and phosphate (-80) from both the SPITC-derivatized and underivatized peptide are present as minor peaks in the spectra. No N-terminal ions were to be found in the spectra. Instead, a prominent yion series was observed. The presence of the $\mathrm{m} / \mathrm{z} 439$ phosphorylated $\mathrm{y} 3$ ion and the $\mathrm{m} / \mathrm{z} 272$ unphosphorylated $\mathrm{y} 2$ ion show that the phosphogroup is located to the second serine of the IHHSSPR phosphopeptide.

Alignment of the N-terminal part of At4g27320.1 and At5g54430.1 with related proteins from other plant species is
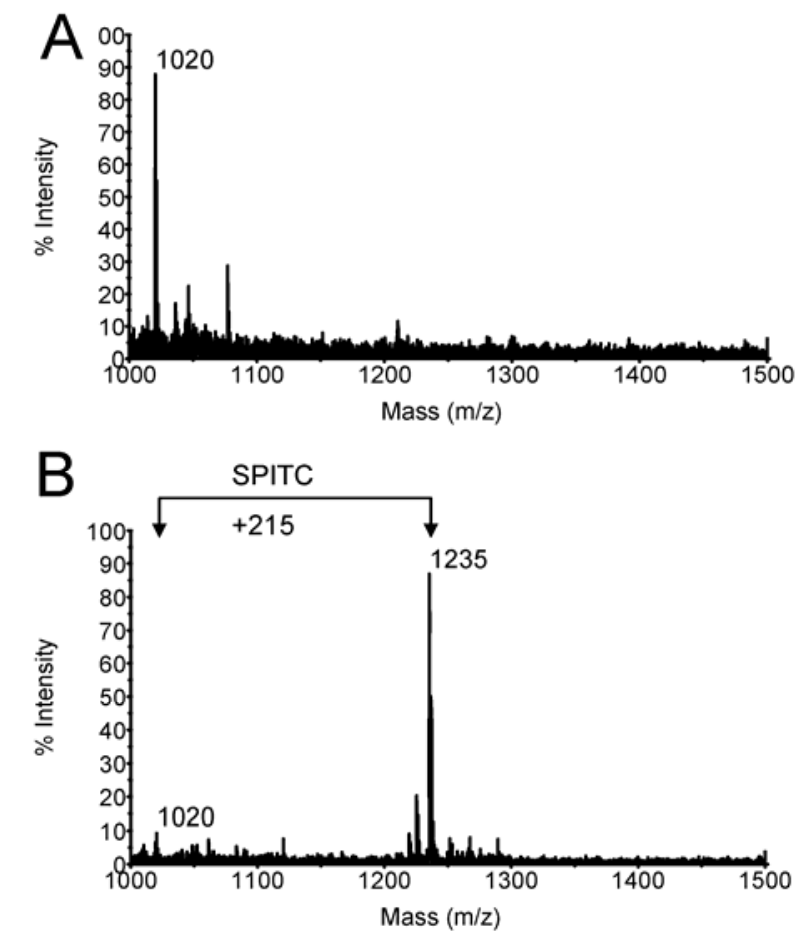

Fig. 5. Matrix-assisted laser desorption ionization mass spectrometry (MALDI MS) spectra of 4-sulfophenyl isothiocyanate (SPITC) labeling of titanium dioxide $\left(\mathrm{TiO}_{2}\right)$-purified phosphopeptide from At5g54430.1. A, $\mathrm{TiO}_{2}$ eluate before derivatization. The major peak is the $\mathrm{m} / \mathrm{z} 1,020$ phosphopeptide. B, SPITC-derivatized $\mathrm{TiO}_{2}$ eluate. The major peak is the derivatized $\mathrm{m} / \mathrm{z} 1,020$ phosphopeptide $(1,020+215=1,235)$. shown in Figure 8. The aligned part does not exist in bacterial USPs. Both proteins that were identified were phosphorylated in this part and, in monocots and dicots, the phosphoserine is conserved.

\section{DISCUSSION}

We have demonstrated how a $\mathrm{TiO}_{2}$ resin can be used for the enrichment of phosphoproteins as well as a method to derivatize $\mathrm{TiO}_{2}$-purified phosphopeptides for facilitating determination of the exact site of phosphorylation. Use of these methods was exemplified by the identification of two plant proteins that could be shown to be phosphorylated after elicitation of Arabidopsis cells with $P$. infestans zoospores and xylanase but not after abiotic stress like salt and sorbitol. This is the first time $\mathrm{TiO}_{2}$ was used to enrich intact phosphoproteins in any biological system.

$\mathrm{TiO}_{2}$ and Ni-NTA enrichments of phosphoproteins showed different phosphoprotein patterns, suggesting that they could be used for the enrichment of partially differing phosphoproteome subpopulations. The Ni-NTA purification was, as expected, found to be dependent on imidazole but not phosphate, with the opposite being the case for $\mathrm{TiO}_{2}$ purification. The phosphate-dependent binding of proteins to the $\mathrm{TiO}_{2}$ resin indicates that the interaction occurred by means of the phosphorylation itself. Indeed, phosphate anions are known to bind strongly to $\mathrm{TiO}_{2}$ in a bidentate bridging configuration (Connor and McQuillan 1999). This is in agreement with the finding that, from the Ni-beads, no differences in protein staining of
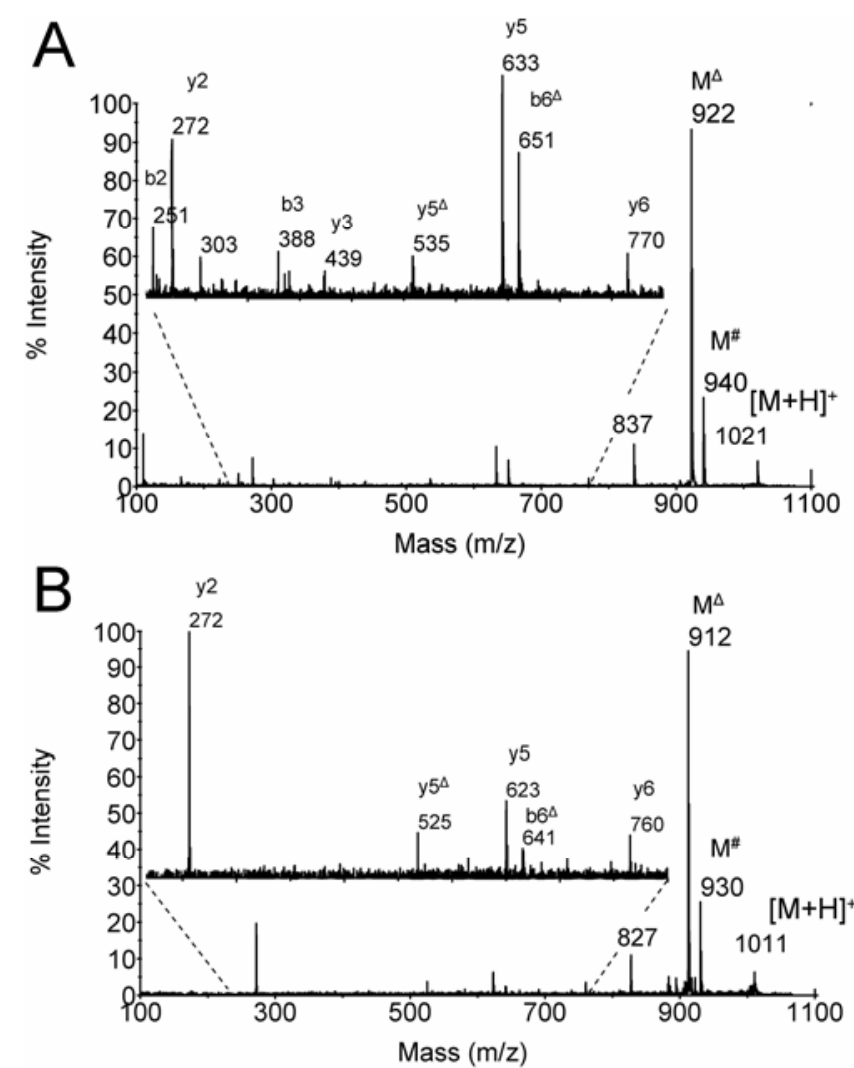

Fig. 6. Matrix-assisted laser desorption ionization mass spectrometry (MALDI MS/MS) spectra of phosphopeptides from At5g54430.1 and At4g27320.1. $\mathrm{y}^{\Delta} / \mathrm{b}^{\Delta} / \mathrm{M}^{\Delta}$ labels ions or fragments that have undergone a neutral loss of phosphoric acid; $\mathbf{M}^{\#}$ labels a fragment that has undergone a neutral loss of phosphate; and $[\mathrm{M}+\mathrm{H}]^{+}$labels the unfragmented parent ion. A, MS/MS spectra of the $\mathrm{m} / \mathrm{z} 1,020$ phosphopeptide. Insert shows enlargement of $\mathrm{m} / \mathrm{z} 250$ to 800 . B, MS/MS spectra of the $\mathrm{m} / \mathrm{z} 1,010$ phosphopeptide. Insert shows enlargement of $\mathrm{m} / \mathrm{z} 250$ to 800 . 
the At4g27320.1 and At5g54430.1 proteins were detected between control and elicited samples. In contrast, hardly any At4g27320.1 or At5g54430.1 protein could be detected in the $\mathrm{TiO}_{2}$-control sample, whereas distinct bands were present in the treated $\mathrm{TiO}_{2}$-bead-enriched samples. It might be the histidine residues on the identified phosphopeptides that are involved in the less phospho-dependent binding to the Ni-beads. This is also in agreement with our detected influence by imidazole on protein-Ni binding in contrast to the protein- $\mathrm{TiO}_{2}$ interaction.

The efficient recovery of known phosphoproteins indicates that even fairly small stochiometic changes in phosphorylation might be detected by the use of $\mathrm{TiO}_{2}$ beads with complementing buffers. The detection of over 10 phosphoproteins from single HPLC MS/MS runs of Arabidopsis samples enriched by $\mathrm{TiO}_{2}$ beads under native and denaturating conditions also show the general applicability of the method. More than half of the phosphoproteins were unique for each buffer, again showing the advantage of using the two different buffers. The MS/MS data of over 20 phosphoproteins taken together with the efficient recovery of phosphoproteins, the clear enrichment shown by the phosphoprotein-stained gels, as well as the inhibition of binding of proteins to the $\mathrm{TiO}_{2}$ beads by addition of phosphate demonstrate that this method could be of general use.

Two proteins were found to be more phosphorylated after challenge of Arabidopsis cells with fungal xylanase and zoospores of $P$. infestans. These two proteins, At5g54430.1 and At4g27320.1, were identified as belonging to a superfamily of USPS (PFAM: PF00582). The USP-domain-containing proteins were first identified in prokaryotic organisms, in which they are known to accumulate in response to a plethora of stimuli, including nutrient starvation, $\mathrm{H}_{2} \mathrm{O}_{2}$, heavy metal, and heat stress (Kvint et al. 2003, Nachin et al. 2005). In plants, the
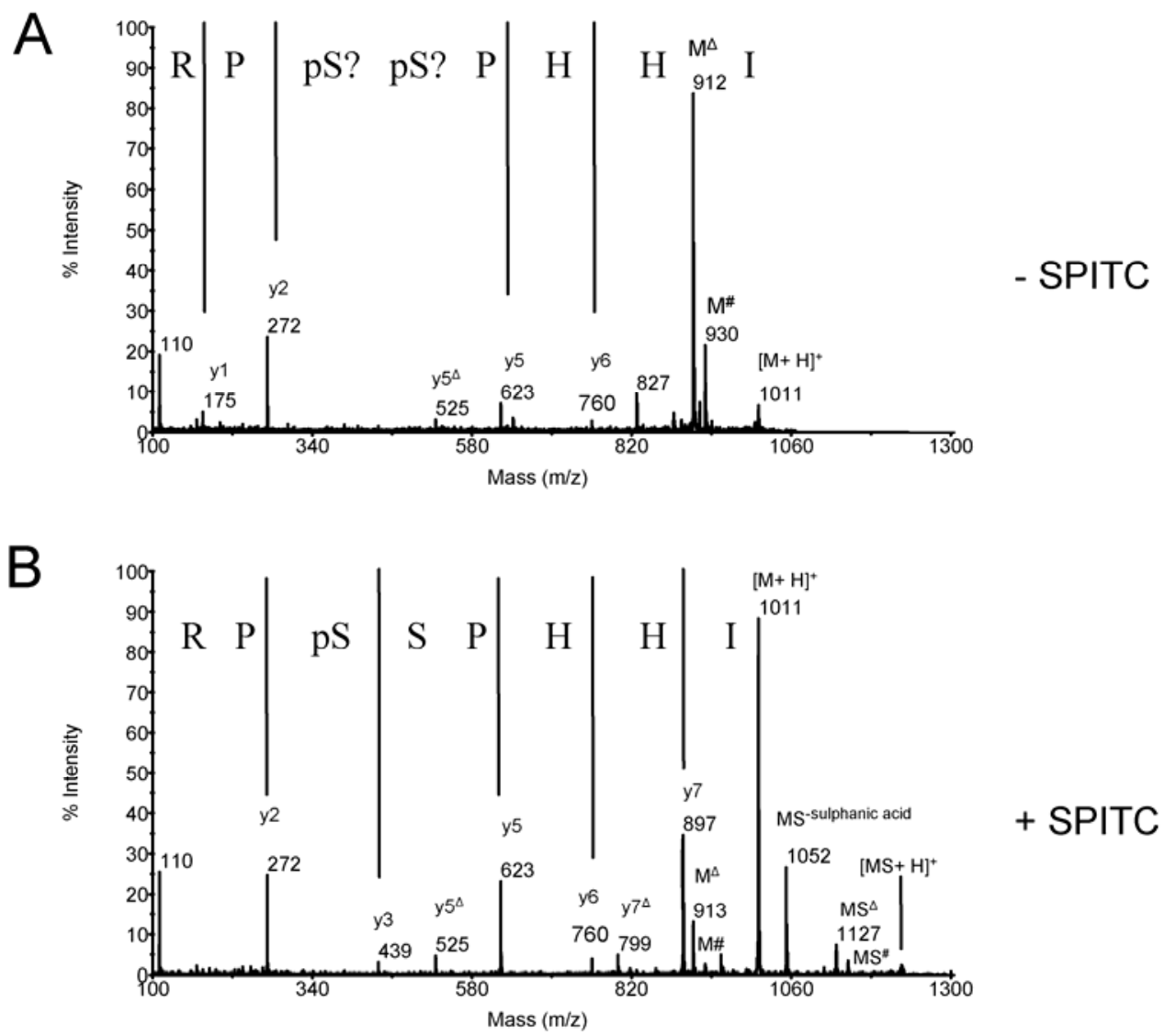

Fig. 7. Matrix-assisted laser desorption ionization dual mass spectrometry (MALDI MS/MS) spectra of the At4g27320.1 phosphopeptide before and after 4sulfophenyl isothiocyanate (SPITC) derivatization. $[\mathrm{M}+\mathrm{H}]^{+}$denotes the parent ion; MS denotes the SPITC-derivatized parent ion; $\mathrm{y}^{\Delta}$ labels a y-ion that has undergone a neutral loss of phosphoric acid; $\mathrm{M}^{\#}$ denotes a parent fragment that has undergone a neutral loss of phosphate; and $\mathrm{M}^{\Delta}$ labels a parent fragment that has undergone a neutral loss of phosphoric acid. A, MS/MS spectrum of the 1,010 phosphopeptide before derivatization. Question marks denote on which residue the phosphogroup might be situated. B, MS/MS spectrum of the SPITC-derivatized phosphopeptide $(\mathrm{m} / \mathrm{z} 1,225)$.

$\begin{array}{ll}\text { At5g54430 } & \\ \text { At4g27320 } & \\ 125934794 & \text { (Bn) } \\ 125936449 & (\mathrm{Bn}) \\ \text { TC228830 } & \text { (Gm) } \\ \text { TC45490 } & \text { (Pop) } \\ \text { TC2771 } & \text { (Pv) } \\ \text { TC177617 } & \text { ( } \mathrm{Sl}) \\ \text { BE616994 } & \text { (Hv) } \\ \text { TC250617 } & \text { (Ta) }\end{array}$

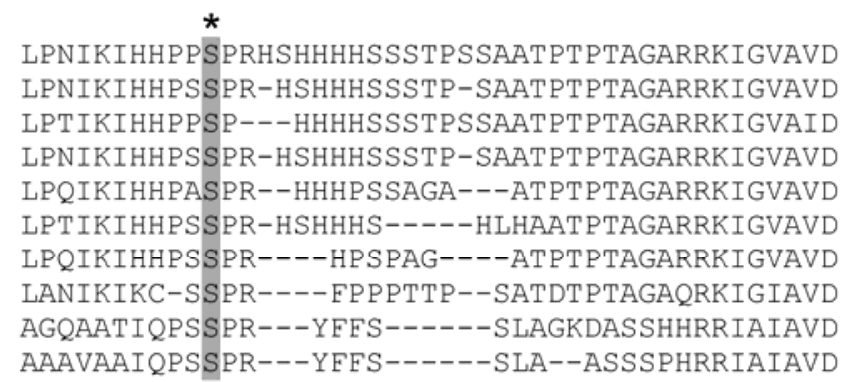

Fig. 8. Alignment of the N-terminal part of At5g54430.1 and At4g27320.1 with apparent plant homologues. The asterisk denotes the phosphorylated serine residue. Bn, canola; Gm, soybean; Pop, poplar; Pv, common bean; Sl, tomato; Hv, barley; and Ta, wheat. 
USP domain is found both in small proteins and together with other functional domains such as protein kinase domains. The biochemical function of the 150-amino-acid residue USP domain is still not clear (Kerk et al. 2003). The structure of the Methanococcus jannaschii protein MJ0577 has been resolved and was found to contain a bound molecule of ATP (Zarembinski et al. 1998). Residues known to be involved in ATP binding were found to be conserved in both of the Arabidopsis proteins identified in this study (Kerk et al. 2003), indicating that these proteins also bind ATP and could function as molecular switches in biotic stress-related cellular processes. This is supported by the fact that these proteins were not phosphorylated upon abiotic stress like salt or sorbitol treatments.

The determination of phosphorylation sites in the proteins that were identified was facilitated by our method for derivatization of $\mathrm{TiO}_{2}$-purified phosphopeptides with SPITC. A prominent $\mathrm{y}$-ion series with no $\mathrm{N}$-terminal ions were present in the spectra. Interestingly, the neutral loss detected in the derivat-

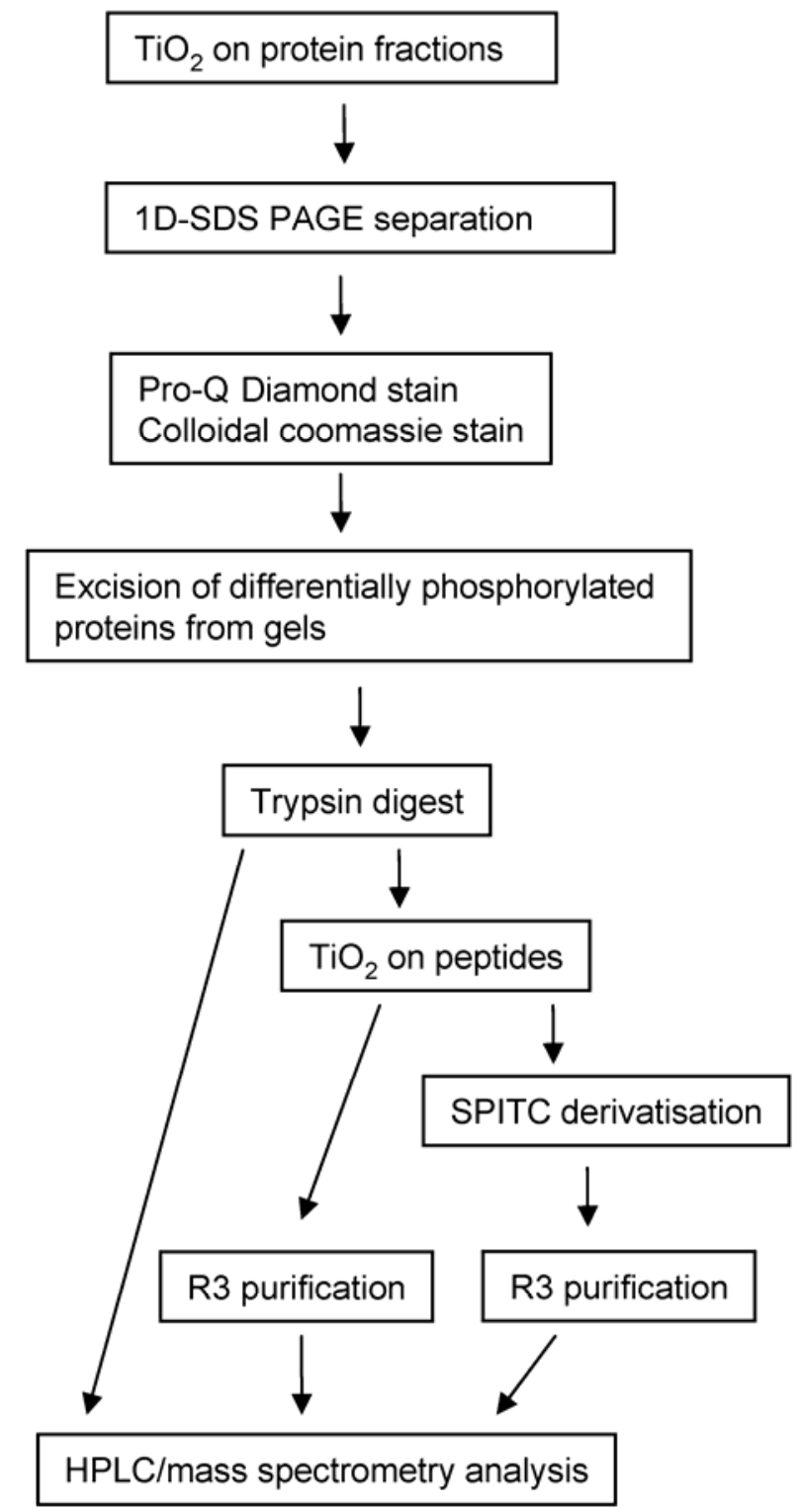

Fig. 9. Summary of methods used in this article and how they relate to each other. Pro-Q Diamond staining visualizes phosphorylated proteins and collodial Coomassie stains proteins. $\mathrm{TiO}_{2}$, titanium dioxide; SDSPAGE, sodium dodecyl sulfate polyacrylamide gel electrophoresis; R3, POROS OLIGO R3 reverse phase chromatography; SPITC, 4-sulfophenyl isothiocyanate; HPLC, high-pressure liquid chromatography. ized samples was less pronounced than in the underivatized samples. This could also help in determining the location of phosphorylation sites. Both proteins were phosphorylated at the N-terminal region (Fig. 4B), a part that does not exist in the USPs from bacteria. The phosphorylation site was found to be conserved in USP-domain-containing proteins from many plant species, including both monocot and dicot plants (Fig. 8). This conservation indicates that phosphorylation of these proteins may have been conserved for more than 100 million years. The phosphorylation of a serine-proline motif means that it is possible that they are substrates of MAPKs known to be activated during responses to xylanase and Phytophthora elicitors (Benschop et al. 2007; Zhang et al. 1998). These proteins show an example where derivatization of the phosphogroup by $\beta$-elimination with $\mathrm{BaOH}$ would be difficult (Adamczyk et al. 2001), which is an important drawback with that method because the SP motif is a target that large groups of kinases have in common.

Many newly developed gel-free quantitative proteomics methods rely on extended access to mass spectrometers with isotopic resolution (Peck and Thelen 2007). For gel-based analyses, less time is required for MS analysis and treatment of data because uninteresting proteins are deselected at an early step. Two-dimensional (2D) gel separation is often used mainly because of its capacity for separating the phosphorylated from the unphosphorylated forms of proteins. However, a limitation of $2 \mathrm{D}$ gels is that they are very poor at separating basic proteins, and many proteins fail to dissolve in the first dimensional loading buffer. The methods for purification of intact phosphoproteins that we describe were found, together with Pro-Q Diamond staining of samples separated by one-dimensional gel samples, to be a robust way of finding differentially phosphorylated proteins (Fig. 9). Identification of phosphopeptides from gel-separated intact proteins can be more straightforward than from gel-free systems, because it is based on information of the size of the proteins and the identification of several peptides from a given protein. Therefore, such methods can be expected to be suitable for many biologists. However, it should be pointed out that a prefractionation step is most probably required to find many interesting differentially phosphorylated proteins in such complex organisms as plants.

One way to identify differentially phosphorylated proteins and to determine the sites of phosphorylation is to excise the gel bands and digest them by trypsin and first analyze a fraction directly by HPLC/MSMS (Fig. 9). If the complexity of the sample is sufficiently low, the protein and phosphopeptide identification as well as determination of the phosphosite can be successful. If no phosphopeptides are identified, however, they need to be enriched prior to HPLC/MSMS (Figs. 4A, 5A, and 9). Increased concentration of ammonia in the elution of peptides from $\mathrm{TiO}_{2}$ and increased TFA concentration in the wash of the R3 column made a significant improvement compared with protocols that were published earlier (Larsen et al. 2005; Zhang et al. 2007). If the sites still cannot be determined, we recommend, especially for TOF users, derivatization of the phosphopeptides by the use of SPITC to get an unambiguous assignment (Figs. 5B, 7, and 9). In addition to phosphosite determination, the SPITC derivatization of peptides is also valid for organisms without a well-annotated proteome in which de novo sequencing is often necessary in order to identify the protein. This is often the case for molecular studies of plantmicrobe interactions.

The USPs described here are the first plant proteins to be shown to be phosphorylated upon treatment with Phytophthora spores. With the definite determination of phosphorylation sites, they are interesting candidates for phosphomimic mutation in order to circumvent the pathogen-driven downregulation of 
kinase activity seen at least in bacteria-plant interactions (Shan et al. 2007).

\section{MATERIALS AND METHODS}

\section{Cell culture and elicitor treatment.}

Suspension cell cultures of A. thaliana ecotype Landsberg (La-e) were used 4 days after subculture of $5 \mathrm{ml}$ of culture into $100 \mathrm{ml}$ (weekly). Cells were treated for $15 \mathrm{~min}$ with a final concentration of xylanase at $100 \mu \mathrm{g} / \mathrm{ml}, 0.1 \mathrm{M} \mathrm{NaCl}, 0.2 \mathrm{M}$ sorbitol, or 300,000 P. infestans zoospores prepared according to Eucablight standards (Swedish isolate 03046 provided by Björn Andersson, Swedish University of Agricultural Sciences). Cells $(50 \mathrm{ml})$ were centrifuged at 4,000 rpm for $2 \mathrm{~min}$ at room temperature. The pellet was immediately frozen in liquid nitrogen and stored at $-80^{\circ} \mathrm{C}$.

\section{Enrichment of phosphorylated proteins.}

Extraction buffer $(16 \mathrm{ml} ; 100 \mathrm{mM}$ morpholineethanesulfonic acid [pH 6.1], $200 \mathrm{mM} \mathrm{NaCl}, 2 \%$ glycerol, $25 \mathrm{mM}$ sodium fluoride, $1 \mathrm{mM}$ sodium molybdate, $0.2 \%$ Tween $20,0.2 \%$ triton $\mathrm{X}-100,10 \mu \mathrm{M}$ leupeptin, $1 \mathrm{nM}$ calyculin A, $1 \mathrm{mM}$ phenylmethylsulfonyl fluoride, and $1 \mathrm{mM}$ sodium orthovanadate) was added to a frozen pellet of plant cells and the mix was sonicated until thawed. Cells were refrozen in liquid nitrogen and sonicated again. Cells were centrifuged at $4^{\circ} \mathrm{C}$ for $5 \mathrm{~min}$ at $4,000 \mathrm{rpm}$ in a swing-out rotor and the supernatant was transferred to a new tube and centrifuged again for $5 \mathrm{~min}$. Binding was done in the extraction buffer or under denaturating conditions according to Wolschin and associates (2005) but with a final urea concentration of $6.4 \mathrm{M}$ urea. Extracts were incubated end over end with $50 \mu \mathrm{l}$ of $50 \%$ Ni-NTA slurry (Qiagen) or $20 \mathrm{mg}$ of $300 \AA$ Sachtophore NP $\mathrm{TiO}_{2}$ beads (Sachtleben Chemie, Duisburg, Germany) at $4^{\circ} \mathrm{C}$ for $2 \mathrm{~h}$. Beads were washed two times for $20 \mathrm{~min}$ with $5 \mathrm{ml}$ of binding buffer. Proteins were eluted from Ni-beads three times in $35 \mu$ of 100 $\mathrm{mM}$ imidazole, $25 \mathrm{mM} \mathrm{NaF}$, and $1 \mathrm{mM}$ sodium molybdate with vigorous shaking for $10 \mathrm{~min}$ followed by incubation for 3 min at $40^{\circ} \mathrm{C}$, unless otherwise stated. The $\mathrm{TiO}_{2}$ beads were eluted the same way with elution buffer $\left(200 \mathrm{mM} \mathrm{Na}{ }_{2} \mathrm{HPO}_{4}\right.$, 75 to $100 \mathrm{mM}$ NaPP, $0.2 \%$ Tween 20 , and $0.2 \%$ triton $\mathrm{X}-100$ with or without $6 \mathrm{M}$ urea). The eluates were pooled before gel separation.

\section{SDS-PAGE.}

Samples were loaded on SDS-PAGE gels alongside $0.4 \mu \mathrm{l}$ of PeppermintStick phosphoprotein molecular weight standards $(0.5 \mu \mathrm{g} / \mu \mathrm{l}$ per protein, Molecular Probes). Gels were stained with Pro-Q Diamond Phosphoprotein Gel Stain according to the protocol provided by Molecular Probes. The gels were analyzed using a Typhoon Scanner (GE Healthcare, Little Chalfont, U.K.) with the use of a 532-nm laser for excitation and an LP 560-nm emission filter. The gels were subsequently stained with colloidal Coomassie. Protein bands of interest were excised from the gel using a scalpel, and stored at $-20^{\circ} \mathrm{C}$ in 1.5 ml maximum recovery tubes (Axygene, Union City, CA, U.S.A.).

\section{In-gel digestion.}

The gel pieces were destained in $100 \mu \mathrm{l}$ of $50 \mathrm{mM}$ $\mathrm{NH}_{4} \mathrm{HCO}_{3}$ in $50 \%$ ethanol three times for 30 min each time. The liquid was removed and $100 \mu \mathrm{l}$ of ethanol was added for $10 \mathrm{~min}$. The gel pieces were rehydrated in $10 \mu \mathrm{l}$ of $10 \mathrm{mM}$

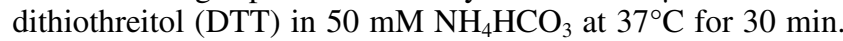
The liquid was removed and $100 \mu$ lof ethanol was added for $10 \mathrm{~min}$. The gel pieces were rehydrated in $10 \mu \mathrm{l}$ of $55 \mathrm{mM}$ iodoacetamide in $50 \mathrm{mM} \mathrm{NH} \mathrm{HCO}_{3}$ and incubated for $30 \mathrm{~min}$ at room temperature in darkness. The liquid was removed and $100 \mu \mathrm{l}$ of $50 \mathrm{mM} \mathrm{NH}_{4} \mathrm{HCO}_{3}$ in $50 \%$ ethanol was added for 5 min. The liquid was removed and $100 \mu \mathrm{l}$ of ethanol was added for $10 \mathrm{~min}$. The gel pieces were rehydrated in $2.8 \mu \mathrm{l}$ of sequencing-grade trypsin at $50 \mathrm{ng} / \mu \mathrm{l}$ (Promega Corp., Madison, WI, U.S.A.) on ice for $45 \mathrm{~min}$. Excess trypsin was removed and $20 \mu \mathrm{l}$ of $50 \mathrm{mM} \mathrm{NH} \mathrm{NCO}_{3}$ was added to cover the gel pieces. The samples were incubated at $37^{\circ} \mathrm{C}$ overnight and the digests were frozen until further use.

\section{In-solution digestion.}

Proteins were reduced with $10 \mathrm{mM}$ DTT at $37^{\circ} \mathrm{C}$ for $1 \mathrm{~h}$. Iodoaceamide was added to a final concentration of $20 \mathrm{mM}$ and the sample incubated at room temperature in darkness for $1 \mathrm{~h}$. Trypsin $(0.1$ to $1 \mu \mathrm{g})$ was added and the samples were incubated at $37^{\circ} \mathrm{C}$ overnight.

\section{Enrichment of phosphorylated peptides.}

Peptides from gel-excised protein bands were purified on handmade pipette tip-columns (epT.I.P.S 0.1 to $10 \mu \mathrm{l}$, no. 0300 073.002; Eppendorf AG, Hamburg, Germany) containing a C8 disk (3M Bioanaytical Technologies, Neuss, Germany) and 2 $\mu l$ of Sachtopore NP beads. Trypsin digests were mixed with 6 volumes of binding buffer (5\% TFA in $80 \%$ ACN). Columns were washed with $25 \mu \mathrm{l}$ of binding buffer and the peptides then loaded onto the column. The column was washed twice with $25 \mu \mathrm{l}$ of binding solution each time, followed by three washes with $0.5 \%$ TFA in $80 \%$ ACN. The peptides were eluted using $20 \mu \mathrm{l}$ of ammonia solution, made with $60 \mu \mathrm{l}$ of $25 \%$ $\mathrm{NH}_{4} \mathrm{OH}$ and $940 \mu \mathrm{l}$ of water. $\mathrm{TiO}_{2}$ eluates were either SPITC derivatized (see below) or acidified with $1 \mu \mathrm{l}$ of concentrated formic acid and purified on a handmade column containing a C8 disk and $2 \mu \mathrm{l}$ of R3 chromatography beads in a $10-\mu \mathrm{l}$ pipette tip. TFA $(0.6 \%)$ was used to wash the column and $20 \mu \mathrm{l}$ of $0.1 \%$ TFA in $80 \%$ ACN was used for elution. Desalted samples were evaporated in a speedvac and reconstituted in $0.5 \%$ TFA before HPLC separation.

\section{SPITC derivatization and purification.}

$\mathrm{TiO}_{2}$-purified phosphopeptides $(20 \mu \mathrm{l})$ in ammonia were mixed with $10 \mu \mathrm{l}$ of $3.3 \%$ formic acid and $10 \mu \mathrm{l}$ of SPITC at $20 \mathrm{mg} / \mathrm{ml}$ in $100 \mathrm{mM} \mathrm{NaHCO}$ and incubated at $55^{\circ} \mathrm{C}$ for 15 $\mathrm{min}$. SPITC at $20 \mathrm{mg} / \mathrm{ml}(5 \mu \mathrm{l})$ was added and again incubated for $15 \mathrm{~min}$ at $55^{\circ} \mathrm{C}$. Concentrated formic acid $(2.2 \mu \mathrm{l})$ was added and the derivatized phosphopeptides purified on R3 with four washing steps with $20 \mu \mathrm{l}$ of $0.5 \%$ TFA and $1 \%$ ACN. SPITC-labeled peptides (+215) were manually selected for MS/MS analysis.

\section{Liquid chromatography.}

Samples were separated by reversed-phase nanoLC using an 1100 Series Nanoflow LC system (Agilent Technologies, Waldbronn, Germany). The mobile phases used for separation were (A) $0.05 \%$ (vol/vol) TFA and (B) $90 \%$ (vol/vol) ACN and $0.05 \%$ (vol/vol) TFA. Digested peptide extract $(8 \mu \mathrm{l})$ was loaded on the column from glass vials. The samples were loaded onto a precolumn (Zorbax 300SBC18, 5 by $0.3 \mathrm{~mm}$ ) at a flow rate for buffer A of $0.050 \mathrm{ml} / \mathrm{min}$. After $14 \mathrm{~min}$, the

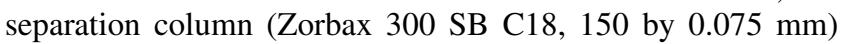
was connected with the precolumn. The separation was carried out at a flow rate of $300 \mathrm{nl} / \mathrm{min}$ with the following elution profile: 10 to $16 \mathrm{~min}, 0$ to $5 \% \mathrm{~B} ; 16$ to $62 \mathrm{~min}, 5$ to $60 \% \mathrm{~B} ; 62$ to $67 \mathrm{~min}, 60$ to $80 \% \mathrm{~B}$; 68 to $72 \mathrm{~min}, 80$ to $100 \% \mathrm{~B} ; 73$ to 78 $\min 100 \% \mathrm{~B} ; 79$ to $80 \mathrm{~min}, 100 \% \mathrm{~B}$. Fractions were collected on MALDI targets from time 16 to $67 \mathrm{~min}$ with 0.5 - to 1 -min intervals using the 1100 Series LC micro collection/spotting system. 


\section{MALDI-TOF MS and MS/MS.}

MS spectra were recorded automatically using a 4700 Proteomics Analyzer (Applied Biosystems, Framingham, MA, U.S.A.) mass spectrometer equipped with an Nd:YAG laser $(355 \mathrm{~nm}$ ) operating at a frequency of $200 \mathrm{~Hz}$. All spectra were collected in positive reflector mode. The instrument was externally calibrated with a mixture of angiotensin $(1,042.542 \mathrm{Da})$ and neurotensin $(1,672.917 \mathrm{Da})$. If present, the obtained MS spectra were internally calibrated using two trypsin autoproteolytic peptides with the $\mathrm{m} / \mathrm{z}$ values 842.51 and 2,211.097 Da. Proteins were identified using the GPS Explorer software, with an in-house Mascot search engine (Matrix Science, London). MS data were first searched with oxidized methionines as a variable modification. Phospho $(\mathrm{S} / \mathrm{T} / \mathrm{Y})$, Deamidation $(\mathrm{N})$ were then added as variable modifications and carbamidomethylation of cysteine residues as static modification. Parameters specified in the search were as follows: missed cleavages, 1; peptide mass tolerance, $\pm 40 \mathrm{ppm}$; and fragment ion mass tolerance, \pm 0.2 to $0.5 \mathrm{Da}$. MS/MS spectra were interpreted manually. The standard matrix was $5 \mathrm{mg} / \mathrm{ml} \alpha$-cyano-4-hydroxy cinnamic acid (Sigma-Aldrich, St. Louis), in 50\% ACN, 0.1\% TFA, and $25 \mathrm{mM}$ sodium citrate.

\section{ACKNOWLEDGMENTS}

We thank N. Gustavsson for setting up the mass spectrometer and for much valuable advice; and the Swedish Research Council for Environment, Agricultural Sciences and Spatial Planning, the Swedish Farmers' Foundation for Agricultural Research, and Carl Tryggers Foundation for providing financial support.

\section{LITERATURE CITED}

Adamczyk, M., Gebler, J. C., and Wu, J. 2001. Selective analysis of phosphopeptides within a protein mixture by chemical modification, reversible biotinylation and mass spectrometry. Rapid Commun. Mass Spectrom. 15:1481-1488.

Anthony, R. G., Khan, S., Costa, J., Pais, M. S., and Bögre, L. 2006. The Arabidopsis protein kinase PTI1-2 is activated by convergent phosphatidic acid and oxidative stress signaling pathways downstream of PDK1 and OXI1. J. Biol. Chem. 281:37536-37546.

Beausoleil, S. A., Jedrychowski, M., Schwartz, D., Elias, J. E., Villén, J., Li, J., Cohn, M. A., Cantley, L. C., and Gygi, S. P. 2004. Large-scale characterization of HeLa cell nuclear phosphoproteins. Proc. Natl. Acad. Sci. U.S.A. 101:12130-12135.

Benschop, J. J., Mohammed, S., O'Flaherty, M., Heck, A. J. R., Slijper, M., and Menke, F. L. H. 2007. Quantitative phosphoproteomics of early elicitor signaling in Arabidopsis. Mol. Cell. Proteomics 6:1198-1214.

Bodenmiller, B., Mueller, L. N., Mueller, M., Domon, B., and Aebersold, R. 2007. Reproducible isolation of distinct, overlapping segments of the phosphoproteome. Nat. Methods 4:231-237.

Caspersen, M. B., Qiu, J., Zhang, X., Andreasson, E., Næsted, H., Mundy, J., and Svensson, B. 2007. Phosphorylation sites of Arabidopsis MAP kinase substrate 1 (MKS1). Biochim. Biophys. Acta 1774:1156-1163.

Chen, P., Nie, S., Mi, W., Wang, X., and Liang, S. 2003. De novo sequencing of tryptic peptides sulfonated by 4-sulfophenyl isothiocyanate for unambiguous protein identification using post-source decay matrixassisted laser desorption/ionization mass spectrometry. Rapid Commun. Mass Spectrom. 18:191-198.

Collins, M. O., Yu, L., Husi, H., Blackstock, W. P., Choudhary, J. S., and Grant, S. G. N. 2005. Robust enrichment of phosphorylated species in complex mixtures by sequential protein and peptide metal-affinity chro- matography and analysis by tandem mass spectrometry. Sci. STKE 298:16.

Connor, P. A., and McQuillan, A. J. 1999. Phosphate adsorption onto $\mathrm{TiO}_{2}$ from aqueous solutions: An in situ internal reflection infrared spectroscopic study. Langmuir 15:2916-2921.

Dubrovska, A., and Souchelnytskyi, S. 2005. Efficient enrichment of intact phosphorylated proteins by modified immobilized metal-affinity chromatography. Proteomics 5:4678-4683.

Gevaert, K., Demol, H., Martens, L., Hoorelbeke, B., Puype, M., Goethals, M., Van Damme, J., De Boeck, S., and Vandekerckhove, J. 2001. Protein identification based on matrix assisted laser desorption/ionizationpost source decay mass spectrometry. Electrophoresis 22:1645-1651.

Keough, T., Youngquist, R. S., and Lacey, M. P. 1999. A method for highsensitivity peptide sequencing using postsource decay matrix-assisted laser desorption ionization mass spectrometry. Proc. Natl. Acad. Sci. U.S.A. 96:7131-7136.

Kerk, D., Bulgrien, J., Smith, D. W., and Gribskov, M. 2003. Arabidopsis proteins containing similarity to the universal stress protein domain of bacteria. Plant Physiol. 131:1209-1219.

Kvint, K., Nachin, L., Diez, A., and Nyström, T. 2003. The bacterial universal stress protein: Function and regulation. Curr. Opin. Microbiol. 6:140-145.

Larsen, M. R., Thingholm, T. E., Jensen, O. N., Roepstorff, P., and Jørgensen, T. J. D. 2005. Highly selective enrichment of phosphorylated peptides from peptide mixtures using titanium dioxide microcolumns. Mol. Cell. Proteomics 4:873-886.

Macek, B., Mijakovic, I., Olsen, J. V., Gnad, F., Kumar, C., Jensen, P. R., and Mann, M. 2007. The serine/threonine/tyrosine phosphoproteome of the model bacterium Bacillus subtilis. Mol. Cell. Proteomics 6:697-707.

Machida, M., Kosako, H., Shirakabe, K., Kobayashi, M., Ushiyama, M., Inagawa, J., Hirano, J., Nakano, T., Bando, Y., Nishida, E., and Hattori, S. 2007. Purification of phosphoproteins by immobilized metal affinity chromatography and its application to phosphoproteome analysis. FEBS (Fed. Eur. Biochem. Soc.) J. 274:1576-1587.

Nachin, L., Nannmark, U., and Nyström, T. 2005. Differential roles of the universal stress proteins of Escherichia coli in oxidative stress resistance, adhesion, and motility. J. Bacteriol. 187:6265-6272.

Peck, S. C., and Thelen, J. J. 2007. Quantitative proteomics in plants: Choices in abundance. Plant Cell 19:3339-3346.

Ron, M., and Avni, A. 2004. The receptor for the fungal elicitor ethyleneinducing xylanase is a member of a resistance-like gene family in tomato. Plant Cell 16:1604-1615.

Shan, L., He, P., and Sheen, J. 2007. Intercepting host MAPK signalling cascades by bacterial type III effectors. Cell Host Microbe 1:167-174.

Thingholm, T. E., Jørgensen, T. J. D., Jensen, O. N., and Larsen, M. R. 2006. Highly selective enrichment of phosphorylated peptides using titanium dioxide. Nat. Protocols 1:1929-1935.

Witze, E. S., Old, W. M., Resing, K. A., and Ahn, N. G. 2007. Mapping protein post-translational modifications with mass spectrometry. Nat. Methods 4(10):798-806.

Wolschin, F., Wienkoop, S., and Weckwerth, W. 2005. Enrichment of phosphorylated proteins and peptides from complex mixtures using metal oxide/hydroxide affinity chromatography (MOAC). Proteomics 5:4389-4397.

Yamamizo, C., Kuchimura, K., Kobayashi, A., Katou, S., Kawakita, K., Jones, J. D. G., Doke, N., and Yoshioka, H. 2006. Rewiring mitogenactivated protein kinase cascade by positive feedback confers potato blight resistance. Plant Physiol. 140:681-692.

Zarembinski, T. I., Hung, L., Mueller-Dieckmann, H., Kim, K., Yokota, H., Kim, R., and Kim, S. 1998. Structure-based assignment of the biochemical function of a hypothetical protein: A test case of structural genomics. Proc. Natl. Acad. Sci. U.S.A. 95:15189-15193.

Zhang, S., Du, H., and Klessig, D. F. 1998. Activation of the tobacco SIP kinase by both a cell wall-derived carbohydrate elicitor and purified proteinaceous elicitins from Phytophthora spp. Plant Cell 10:435-449.

Zhang, X., Ye, J., Jensen, O. N., and Roepstorff, P. 2007. Highly efficient phosphopeptide enrichment by calcium phosphate precipitation combined with subsequent IMAC enrichment. Mol. Cell. Proteomics 6:2032-2042. 